\title{
SOCIAL, ECONOMIC, AND POLITICAL ASPECTS OF THE DEVELOPMENT OF THE PUBLIC ADMINISTRATION SYSTEM: THE EXPERIENCE OF RUSSIA AND THE COUNTRIES OF THE BALTIC REGION \\ Elena Zolochevskaya ${ }^{1}$, Mariya Shtepa ${ }^{2}$, Armine Babayan ${ }^{3}$
}

\begin{abstract}
The growing macroeconomic and political tensions between Russia and the Baltic States since the latter entered into the European Union have emphasized an urgency in establishing reciprocal relationships, based on common ground and mutual interests, to relieve the consequences of sanctions and restrictive policies. The article is aimed at highlighting the distinctions in the public administration framework in Russia and Baltic countries. Thus, the political power from forming a system of public administration can leverage influence on the social and economic relations in conditions of legitimacy and participation of civil society arrangements. The article involves comparative evaluation of Russian and Baltic model of public administration as well as deep comparison of public-private partnership (PPP) and state procurement models in Russia and abroad. Authors highlighted pros and cons of both Russian and foreign frameworks, resulting in "cooperation-prosperity" course.
\end{abstract}

JEL Classification Numbers: D60, H10, I28; DOI: http://dx.doi.org/10.12955/cbup.v6.1207

Keywords: public administration, social-economic relations, education

\section{Introduction}

The concept of public administration realizes the increasing involvement of society in monitoring, assessing, and controlling relationships between state authorities' and the civil and business communities that are needed to achieve goals and interests of all parties. The public interests and needs are underlined. Mechanisms for involving civic institutions in socially significant managerial decisions are implemented. Public consultation is used as a means of ensuring the legitimacy of administrative decisions and the consolidation in the normal acts of harmonizing the interests as conditions of a democratic society.

All modern states (with a few exceptions) use a public administration model based on historical management traditions that use the specifics of social and economic development, the resource potential, and the economic and political formation for the standard of living and the maturity of democratic institutions. At the same time, the structure and mechanisms of national systems of public administration are significantly influenced by globalization and the development of the information society. A common sign in all existing social systems is the basic contradiction of public management. Although an objective need is to strengthen the public's view of management, the system in effect alienates the public in the adoption of managerial decisions. The need to resolve this contradiction and to avail resources for improving the effectiveness of public administration indicate the relevance of research into effective models of public administration systems. Hence, the aim of this article is to compare and evaluate the public administrations of Russia and the Baltic States.

Comparative Evaluation of Public Administration in Russia and the Countries of the Baltic Region

In comparing the Anglo-Saxon and continental European models of public administration, it is noted that, to date, in democratically developed countries, there are no fundamental differences between these two models. Their modern forms, which are largely the result of reforms in public administration, show a certain convergence. The characteristic features of the modern continental European model are a combination of the local government system and the activities of local administrations (state and local authorities) in election and appointment. There is a certain hierarchy of the management system in which local government is at a lower level than the state. There is also

\footnotetext{
${ }^{1}$ Department of Management, Russian Presidential Academy of National Economy and Public Administration (RANEPA), Russia, zolochevskaya@uriu.ranepa.ru

${ }^{2}$ Department of Management, Russian Presidential Academy of National Economy and Public Administration (RANEPA), Russia, shtepa@uriu.ranepa.ru

${ }^{3}$ Department of Management, Russian Presidential Academy of National Economy and Public Administration (RANEPA), Russia, Arminebabaian@yandex.ru
} 
limited autonomy of local self-government and a working presence of special state commissioners, who control local self-government bodies.

It is relevant to conduct a comparative analysis of public administration elements in Russia and the Baltic States regarding the creation and functioning of the institutions of public and private partnerships (PPP), e-government, electronic state and municipal services, and public procurement.

One institutional feature of forming the public administration in the Baltic States, where both the state and the society were reforming, was the absence of a significant social stratification for Russia and excessive privileges from the state-administrative bureaucracy. The process of modernizing the Baltic States was "more smooth, transparent and legal, less criminal and, most importantly, more painless than in Russia" (Simonyan, 2009, p.121). The source of a relatively fast development is a civil society, as Simonyan (2009, p.46) stated: "unlike, for example, from Russia, the local population is willing ... to actively participate in these processes."

The domestic experience of building a public administration system emphasized the need for a vector to increase the transparency of implementing the functions of government bodies. This was the experience that entailed the start in transforming public administration into public management. It determined the direction and content of subsequent institutional changes in the social and economic system of Russia (Khalilova \& Romanova, 2014).

Today in Russia, PPP projects are mainly implemented in the housing and communal services with the building of roads, railways, and ports. However, their implementation is not without shortcomings. There is an objective need for clear, consistent, and targeted actions in the institutional, legal, organizational, financial, economic, scientific, and social spheres to ensure the effective development of the domestic public and private partnership system, as well as the replacement of inefficient and traditional models for those effective and adequate for domestic practices, such as the innovative PPPmodels.

Regarding the history of PPP use by the Baltic States, after accession to the European Union (EU), these countries had to solve a complex problem, i.e., to reduce the existing imbalance in the quality and accessibility of public services and at the same time, ensure financial stability, primarily in terms of budget discipline. At the beginning of their transition to a market economy, the Baltic States, similar to other countries in the region, inherited extensive infrastructure networks, which were in substandard condition and negatively affected their economies. Today in these countries, the transport sector, which oversees roads, the construction of bridges and tunnels, rail, and airports, is leading the PPP application. Following, after a significant gap, are health care, education, water supply, and sanitation (Moiseeva \& Kochetkova, 2015).

Thus, Russia and the Baltic countries are in similar positions on the formation of a PPP infrastructure, Their measures are also similar in the procedures for developing standards and legislation in the field of PPPs, the creation of a state body for implementing PPPs, and the development of a PPP agreement structure. Their positions are also the same for creating an interactive system, constructing an open market for PPP participants, and adapting the experience of other countries for use in the domestic market.

\section{PPP Projects as a Tool for Strategic Development of Modern Infrastructure Facilities}

Projects of PPP in Russia and the Baltic countries can become a strategic direction for developing and modernizing current infrastructure facilities. The element of public administration, i.e., the system of e-government and provision of state and municipal services, differs between Russia and the Baltic States in terms of development and functional capabilities. Certainly, state and municipal services are factors in developing a civil society. They are a sign of a service state and a public recognition of its management. As the experts note, "the entry of the term 'public services' into modern lexicon marks profound transformations that are associated with a change in the role and functions of the state in modern society" (Tereshenko, 2004, p. 15), which indicates a change in the paternalistic role of the state that controls all spheres of life with public management performing the functions expected by society. According to Murzina (2010),

The development of this [public service] institution can greatly affect the basic cultural attitudes of the population, gradually introducing it to a new, more equal style of relations with the state and gradually contributing to the destruction of paternalistic stereotypes. (p. 36) 
In May 2008, the government of the Russian Federation approved the Concept of the Formation of the Electronic Government in Russia. Subsequently, the sphere of rendering state and municipal services, interdepartmental interaction, and public procurement was optimized and the principles of public administration implemented. Thus, there is a direct causal relationship between the development of state and municipal services and the enhanced effectiveness of state public administration.

However, in the public management of state services in Russia, the following contradictions remain:

- The fair observance of interests and needs of recipients of public services along with unlikelihood of effectively meeting these needs under conditions of limited resources; and

- The objective need to analyze public opinion to improve the effectiveness of the public service in contrast to the lack of a mechanism to take such a need into account in the managerial decisions of authorities.

Monitoring of public opinion on the quality of the public service through the portal, Vashkontrol, fails to meet the requirement of representativeness, as posting a response about the service and the service provider is voluntary. The results of the last field studies were posted on the portal, Vashkontrol, dating back to 2014. The All-Russian Center for the Study of Public Opinion in 2015 published the results of the survey 'State services online: user evaluations' and presented estimates of the users of electronic public services. This was on the basis that it would be incorrect to formulate a conclusion about the citizens' satisfaction with the quality of the entire range of public services in general (including those not provided in electronic form). This indicated that the study lacked genuine public opinion regarding the results of public administration in the sphere of public services.

Russia, in developing its own e-government, relied on the experience of Estonia. Since 2010, it studied the experience of the Estonian electronic election system, the functioning of Estonia's national electronic identity card system, Estonia's mobile phone identification system, and its inter-agency information communication systems.

However, in adapting the experience of Estonia, Russia had a number of significant restrictions, including territorial ones. The number of Internet users in Russia at the age of 16 years or older was about 84 million people at the time (GfK study, 2017). This number is 60 times the population of Estonia with the percentage of Internet coverage almost half that in this small country.

Among the Baltic countries, Estonia occupies one of the top places in the ranking of countries in terms of the availability of electronic services, which it initiated in 1997 (the program 'Tiger Leap'). The comprehensive approach produced noteworthy results. These included the large-scale training of residents in using the Internet, computerization of the country, authorities replacing paper documents with electronic formats, and a system of electronic banking. Over one hundred databases were integrated into a system of interdepartmental data exchange, which simplified the filing of documents, including tax returns, for users of electronic public services. Public services for obtaining information, electronic tickets for public transport, receiving prescriptions for medicines, and paying for parking lots, have been converted into an electronic format. For legal entities, the list of electronic services includes submitting applications to the authorities, e.g., for a work permit or compensation regarding an anti-corruption potential.

Particular focus was given to the system of electronic voting involving identification cards, which are mandatory forms of identifying voters i.e., an electronic signature that allows individuals to participate in elections from anywhere in the world providing they have access to the Internet.

The system of public services in Russia is progressing with some services available electronically. Without applying to the authority (Rosreestr), it is possible to file an application and initial information electronically, minimizing the frequency of direct contact for the authority providing the public services.

\section{Education as an Element of the Public Administration}

The transformation of knowledge into basic social capital and the increase in benefits associated with acquiring knowledge promotes the establishment of education as a service. The specificity of education as a service is that it benefits the person who consumes the service, as well as the specific enterprises and society as a whole, which justifies the expansion and diversification of funding sources (Tikhonov et al., 2013). 
The revealed specificity is the basis for preferring a mixed source of financing for education compared with purely state or private. In addition, mixed financing is preferable both in public and private educational institutions.

Strengthening the degree of public character in managing the education system is a basic condition for resolving existing contradictions. Hence, the prerequisites for introducing a conceptual model of the public management of public services in Russia include

- feedback from consumers of services,

- information openness,

- monitoring of public opinion on the quality of public services,

- interdepartmental electronic interactions, and

- the public institutions acting to protect the rights and account for the opinions of recipients of public education services in the development of e-learning environments.

\section{The State Order System as One of the Institutions of Public Administration}

The system of state procurement is an institution of public administration. The system of state order is an important part of the financial sector of the Russian Federation. It almost covers all segments of the national economy and social sphere. Over the past few years, the volume of budget expenditure in Russia has systematically increased and this has directly affected the amount of funding available through public procurement. When government spending on purchasing goods, works, and services reaches $30-40 \%$ of the expenditure share of the federal budget and 10-15\% of gross domestic product (GDP), the task of strengthening the public character of the public procurement management, based on the principles of transparency, democracy, and a civil society participating in its business structures. In light of this problem was formed the Federal Law of the Russian Federation of April 5, 2013, No. 44FZ 'On contract system in the sphere of procurement of goods, works, services for the provision of state and municipal needs'.

However, various contradictions that impede the imperative of publicity emerge in the practical functioning of a modern system of public administration in the sphere of state procurement. This is due to the complexity of the emerging structural and functional relationships of the subject with the object, the uncertainty of the external environment, and the presence of intra-systemic problems. Thus, the main contradiction of public administration systems is the objective need to strengthen the publicity of procurement while there is a growing tendency towards deterring the representatives of civil society and business structures from developing and adopting resolutions aimed at regulating the procurement process. The determent, in this case, is due to a high degree of public distrust in authorities and, in turn, predetermines the low functional effectiveness of public administration in the sphere of state procurement. (Figure 1).

Transforming social and economic affairs in the sphere of public procurement justifies having an integrated approach towards managing this sphere. The evolving trend in the procurement management system in recent years has been the increasing comprehension of needing to use public administration tools and participatory mechanisms in the management of the partnership between the state, business, and civil society. This is because the current situation in the country's development portrays the need to search for new, more stable and promising forms of cooperation between the state and members of the public in order to increase the effectiveness of government bodies and the quality of life for the population.

In Latvia, where the Law 'On Public Procurements' operates and such procurement is rapidly developing, in 2016 the public procurement contracts totaled more than EUR 2759 million, which was $11.16 \%$ of the country's gross domestic product (Public Sector Procurement, Latvian Procurement Monitoring Bureau, 2017).

Under the law of Latvia, an applicant applying to participate in a competition is audited for bankruptcy and money owing in taxes, including debts to social insurance payments of more than EUR 150 . Restrictions are introduced for applicants in terms of pay for employees where the average rate for an occupation is at least $80 \%$ of the average hourly rate for the country. Applicants need to prove that they do not pay salaries in cash (avoiding payment of tax) by attaching a certificate from the Electronic Declaration System (Khramenkova, 2016). 


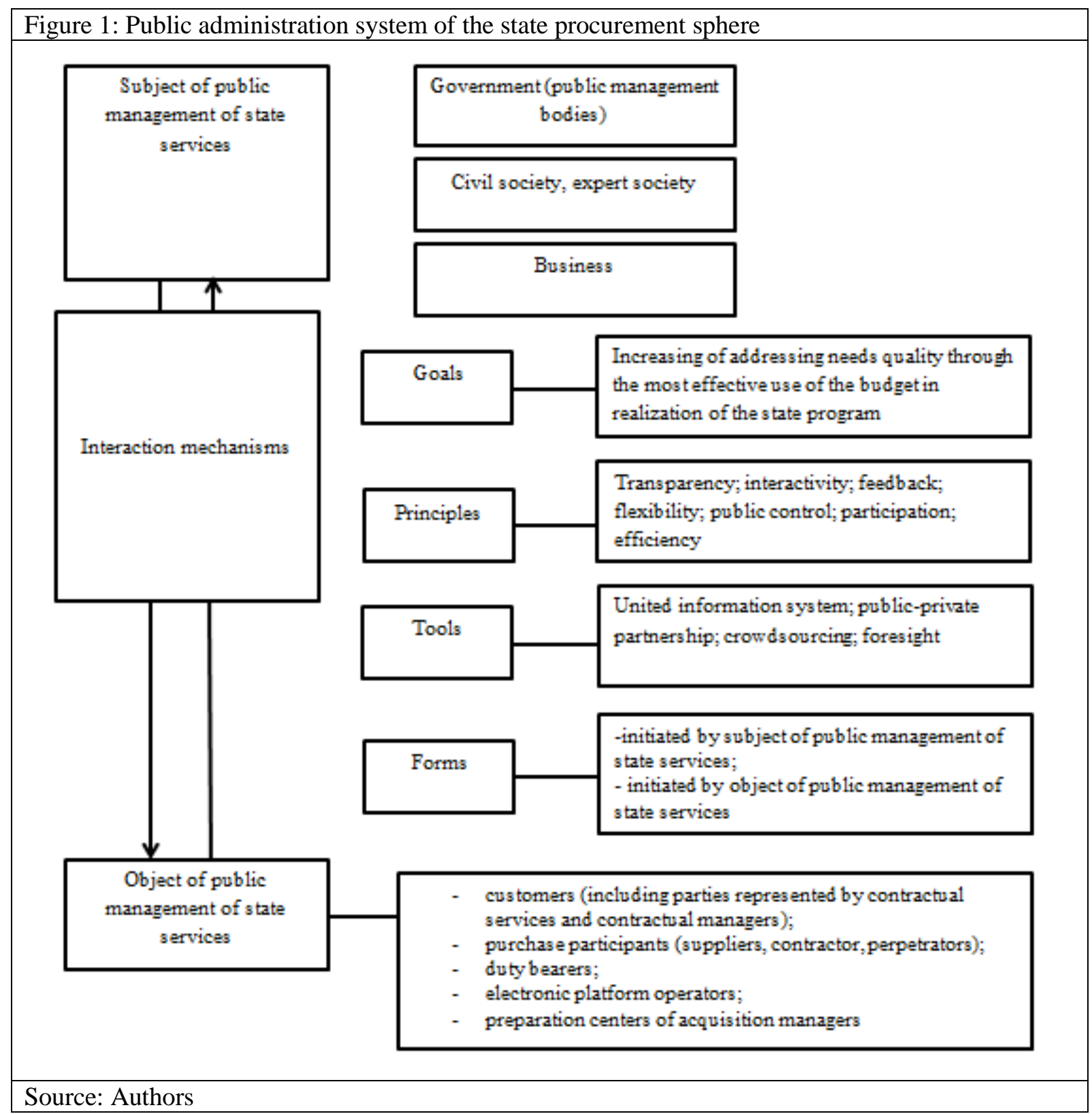

The experience of Russia and the Baltic States show that it is necessary to incorporate a new public participation tool, a public audit, into the institutional environment to implement the state order as an integrated tool for engaging the private sector in the process of managing the contractual system.

The public audit can be a synthesis of various forms of public control in the contractual system including tools for implementing a public initiative for improving the procurement policy of the state. It can be carried out using the Internet platform, such as the Unified Information System. In the field of procurement, conditions for public discussion of auctions and competitions are created and the results are included in the minutes of the public discussion and entail procedural and legal consequences. At present, participation in public discussions is an ineffective means of ensuring publicity of the procurement process. Of the 356 applications available for public discussion, as of November 7, 2017, 7.3\% had comments from independent experts. The minutes of the public hearing regarding the rest included the phrase 'there have been no comments or suggestions'. Hence, it is necessary to popularize the possibility of influencing procurement through mass media and forming a system of incentives for experts who identify the inconsistencies in the procurement procedure. This will help resolve public procurement controversies that are based on forming a participatory civil society. In addition, transferring some managerial procedures to expert communities will allow public 
administration authorities to make management decisions that are appropriate public preferences and provide them with additional intellectual resources for adjusting the state procurement policy.

\section{Conclusion}

The relations between Russia and the Baltic States in the economic, political, and social spheres, after the collapse of the USSR, have tended to involve alienation, mutual historical grievances, and other claims. At the same time, neither side has been without subjectivity nor clichés in perceiving the other. Resources needed for development are not offered in a plane of confrontation, but rather in a field of common ground with mutual interests and goals, and in negotiating solutions for existing problems. Hence, it is necessary to initiate a return to the dialogue in the format of the Council of the Baltic Sea States that was discontinued after the Ukrainian crisis, and use opportunities to share experience and joint developments.

\section{References}

Hramenkova N. (2016) Expenses on state procurements in Latvia make more than 11\% of GDP//the Baltic course. News and analytics. Electronic resource. URL: http://www.baltic-course.com/rus/_analytics/?doc=114400.

Khalilova M.A., Romanova Yu.A. (2014) Efficiency of public management in the Russian Federation//Management of economic systems: online scientific magazine. No. 1. URL: http://cyberleninka.ru/article/n/effektivnost-publichnogoupravleniya-v-rossiyskoy-federatsii

Moiseyeva I. In, Kochetkova S.A. (2015) Ways of financing of PPP projects: foreign experience and possibilities of his use in Russia//the International magazine of applied and basic researches. - No. 12-7. - Page 1281-1286

Murzina I.A. (2010) Improvement of institute of public services as factor of formation of civil society//News of the Saratov university. - T. 10. It is gray. Sociology. Political science, issue 2. - Page 36.

Publiskg sektora iepirkumi. Iepirkumu uzraudzMbas birojs. (2017) Electronic resource. URL:

http://www.iub.gov.lv/lv/mekletiepirkumus.

Research GfK: Tendencies of development of Internet audience in Russia. (2017)//Electronic resource, URL: http://www.gfk.com/ru/insaity/press-release/issledovanie-gfk-tendencii-razvitija-internet-auditorii-v-rossii/.

Simonyan R.H. (2009) Russia and Baltic States. Two models of social development. Prod. the 3rd. M.: - 416 pages.

Tereshenko L.K. (2004) Services: state, public, social//Magazine of Russian law. - No. 106 pp. 15-23

Tikhonov A.N., Abrameshin A.E., Voronina T. P., Ivannikov A.D., Molchanova O.P. (2013) Management of modern education: social and economic aspects Electronic resource, URL: http://www.edu.ru/db/portal/e-library 